\title{
Domestication strategies for the endangered catfish species Pseudopimelodus mangurus Valenciennes, 1835 (Siluriformes: Pseudopimelodidae)
}

\author{
G. F. Shiguemoto ${ }^{a, b}$ (D), D. R. Arashiro ${ }^{a, b}$ (D), N. Levy-Pereira ${ }^{c^{*}}$ (D), S. C. A. Santos ${ }^{\text {, }}$, \\ J. A. Senhorini ${ }^{b}$ (D), P. S. Monzani ${ }^{b}$ (D) and G. S. Yasui ${ }^{a, b}$

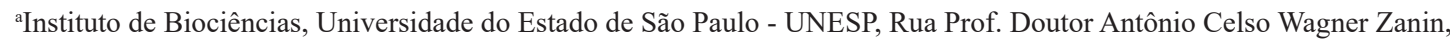 \\ s/n, CEP 18618-689, Botucatu, SP, Brasil \\ ${ }^{b}$ Laboratório de Biotecnologia de Peixes, Centro Nacional de Pesquisa e Conservação da Biodiversidade Aquática \\ Continental, Instituto de Conservação da Biodiversidade Chico Mendes, Rodovia Pref. Euberto Nemésio Pereira de Godoy, \\ CEP 13630-970, Pirassununga, SP, Brasil \\ 'Departamento de Medicina Veterinária - FZEA, Universidade de São Paulo - USP, Avenida Duque de Caxias Norte 225, \\ CEP 13639-080, Pirassununga, SP, Brasil \\ ${ }^{d}$ AES Tietê, Br-153, Rod. 0 Km 139, Centro, CEP 16370-000, Promissão, SP, Brasil \\ *e-mail: nycolas.pereira@zootecnista.com.br
}

Received: June 05, 2019 - Accepted: Jan. 21, 2020 - Distributed: May 31, 2021

(With 5 figures)

\begin{abstract}
Wild fish domestication can be considered a strategic approach to endangered species conservation, supporting studies and reducing economic and environmental costs. Three of the most important strategies in the domestication processes of fish are the adaptation of wild fish to captivity, the reproduction of the adapted fish and the production and maintenance of the young individuals. That being said, the present study is divided in three experiments: the $1^{\text {st }}$ aimed to adapt wild Pseudopimelodus mangurus to captivity environment using different feeding approaches and a prophylactic strategie; the $2^{\text {nd }}$ aimed to reproduce the adapted individuals from the $1^{\text {st }}$ experiment; and the $3^{\text {rd }}$ aimed to train the P. mangurus juveniles to accept commercial diets. The $1^{\text {st }}$ and $2^{\text {nd }}$ experiments were successful at the maintenance and artificial reproduction of $P$. mangurus kept in tanks between the reproductive seasons. The results suggest that the reproductive performance of animals kept in captivity (initial relative fertility-IRF $=609.25 \pm 36.6 \mathrm{eggs} / \mathrm{g}$ ) was $\operatorname{similar}(p>0,05)$ to the performance found in wild individuals (IRF $=679.21 \pm 45.66 \mathrm{eggs} / \mathrm{g}$ ). Feed training of $P$. mangurus juveniles ( $3^{\text {rd }}$ experiment) was also conducted, evaluating three feeding treatments with different concentrations of bovine heart and ration. At the end of the experiment, the treatment containing half bovine heart and half commercial feeding resulted in the highest values of weight gain $(0.10 \pm 0.16 \mathrm{~g})$, specific growth rate $(0.37 \pm 0.11 \mathrm{~mm})$, length $(47.78 \pm 2.35 \mathrm{~mm})$ and growth $(2.15 \pm 2.27 \mathrm{~mm})$, suggesting reasonable acceptability to artificial diets in the cultivation of this species. As conclusion, the present study contributes with the development of techniques for the domestication of fresh water fish species with commercial value or andangered of extinction, showing the domestication and reproduction of wild P. mangurus in captivity. However, more studies have to be conducted in order to improve the acceptance of artificial feeding by juveniles and to increase their survival rate.
\end{abstract}

Keywords: aquaculture, artificial reproduction, conservation, feed training, marbled catfish, Siluriforms.

\section{Estratégias de domesticação das espécies ameaçadas de peixe-gato Pseudopimelodus mangurus Valenciennes, 1835 (Siluriformes: Pseudopimelodidae)}

\begin{abstract}
Resumo
A domesticação de peixes selvagens pode ser considerada uma abordagem estratégica para a conservação de espécies ameaçadas, apoiando estudos e reduzindo custos econômicos e ambientais. Três das estratégias mais importantes para o processo de domesticação de peixes são a adaptação dos peixes ao cativeiro, a reprodução dos peixes adaptados e a produção e manutenção dos indivíduos jovens. O presente estudo está dividido em três partes: a $1^{a}$ objetivou adaptar Pseudopimelodus mangurus selvagens ao ambiente de cativeiro usando diferentes abordagens alimentares e uma estratégia profilática; o $2^{\circ}$ objetivou reproduzir os indivíduos adaptados do $1^{\circ}$ experimento; e o $3^{\circ}$ teve como objetivo treinar os juvenis de P. mangurus para aceitar dietas comerciais. $\mathrm{O} 1^{\circ}$ e $2^{\circ}$ experimento obteveram sucesso na manutenção e reprodução artificial de $P$. mangurus mantidos em tanques entre as estações reprodutivas. Os resultados sugerem que o
\end{abstract}


desempenho reprodutivo dos animais mantidos em cativeiro (fertilidade inicial relativa-FIR $=609,25 \pm 36,6$ ovos $/ \mathrm{g}$ ) foi similar $(\mathrm{p}>0,05)$ ao dos indivíduos selvagens ( $\mathrm{FIR}=679,21 \pm 45,66$ ovos $/ \mathrm{g})$. O treinamento alimentar de $P$. mangurus juvenis ( $3^{\circ}$ experimento) também foi realizado avaliando-se 3 tratamentos alimentares com diferentes concentrações de coração bovino e ração. Ao final do experimento, o tratamento contendo metade coração bovino e metade ração gerou os maiores valores de ganho de peso $(0,10 \pm 0,16 \mathrm{~g})$, taxa de crescimento específico $(0,37 \pm 0,11 \mathrm{~mm})$, comprimento $(47,78 \pm 2,35 \mathrm{~mm})$ e crescimento $(2,15 \pm 2,27 \mathrm{~mm})$, sugerindo razoável aceitabilidade para dietas artificiais no cultivo desta espécie. Como conclusão, o presente estudo contribui com o desenvolvimento de técnicas para a domesticação espécies de peixes de água doce, de interesse comercial ou ameaçados de extinção, mostrando a domesticação e reproduçao de em cativeiro P. Mangurus selvagens. No entanto, mais estudos devem ser conduzidos no intuito de aumentar a aceitação de dietas comerciais pelos juvenis e melhorar sua taxa sobrevivência.

Palavras-chave: aquicultura, reprodução artificial, conservação, treinamento alimentar, bagre sapo, Siluriformes.

\section{Introduction}

Anthropogenic activities such as changes in the natural courses of rivers, pollution, deforestation, introduction of alien species and overfishing are deleterious to natural fish populations (Sobjak et al., 2017). Moreover, environmental disasters, such as occurred in the Brazilian cities of Mariana (2015) and Brumadinho (2019), leads to almost instantaneous death of hundreds of thousands of fish species and other life forms, strongly affecting the natural fish stocks and, consequently, the regional socioeconomic activities (Carvalho et al., 2017; Santos et al., 2018; Lopes et al., 2019; Pereira et al., 2019; Rudorff et al., 2018).

In this regard, according with the IUCN Red List of Endangered Species (Icmbio, 2018), only in the Neotropical region, 410 species are considered endangered. This demands conservation efforts in order to attenuate the status of such fish species, including ex-situ genebanks (Comizzoli \& Holt, 2014). In fish, the most studded and performed procedures for genebanking are the maintenance of live fish in artificial ponds and the cryobanking into liquid nitrogen. However, before the establishment of such a conservation strategy, the first bottleneck that arise regards in the capture and domestication of wild specimens. In fact, the maintenance per se does not ensure the conservation of a given species, because the fish may be lost by death or poor traceability. Then it is necessary to establish procedures of artificial propagation to ensure the long-term viability of genebanks (Gorda et al., 1995). In addition, wild-caught fish generally does not accept artificial diets such as commercial pellets giving rise to low survival. To feed the fish with natural food items is difficult to proceed in large scale and are both, time consuming and economically impracticable. In the case of carnivorous species, the administration of live fish also does not give satisfactory results because the fish does not eat for long periods after capturing, period in which survival is critical.

The marbled catfish Pseudopimelodus mangurus (Valenciennes, 1835) is an endangered fish species from the Neotropical region, recently listed in the Red Book of Endangered Fauna in the State of São Paulo (Sugieda et al., 2010). The P. mangurus is a carnivorous catfish from the order of Siluriformes, distributed in the basins of the rivers Uruguay, Paraná, Paraguay, and La Plata, and can reach more than $8 \mathrm{~kg}$. Moreover, $P$. mangurus plays an important role in the ecosystems where is endemic, acting in the population dynamics as predator and serving as food for birds and reptiles. Although unexploited in aquaculture, this species is part of the subsistence of thousands of fisherman families, presenting good meat quality and no intramuscular bones (Schuingues et al., 2013; Wagner et al., 2002), making it a potential candidate species for freshwater aquaculture.

According to the consulted literature, there are no reports concerning procedures of capture and maintenance P. mangurus in artificial conditions, as well as regarding its reproduction and feed training of juveniles. Thus, in order to develop conservation strategies for the P. mangurus, this research was divided into three experiments: the $1^{\text {st }}$ and $2^{\text {nd }}$ experiments aimed to domesticate and breed, respectively, wild-caught $P$. mangurus and, the $3^{\text {th }}$ experiment aimed to determine a protocol of feed transition for juveniles, evaluating the productive parameters and survival.

\section{Material and Methods}

\subsection{Ethical standards}

All the procedures were performed according with the standards of the Ethics Committee on Animal Use (CEUA/CEPTA \#010/2015) of the National Center for Research and Conservation of Continental Aquatic Biodiversity - ICMBio - CEPTA. Fish capture from wild was conducted with the permission (Sisbio \#60.383-1).

\subsection{Experiment I: domestication of wild-caught adult P. mangurus}

During the first semester of 2017, 30 wild-caught individuals of P. mangurus (9 males with $0.670 \pm \mathrm{g}$ and 21 females with $1.224 \pm \mathrm{g}$ ) were collected from Mogi Guaçú river (Pirassununga city, São Paulo State, Brazil, $21^{\circ} 55^{\prime} 36.476$ “S, 47 $22^{\circ}$ '0.836” W), using line and hook $(>5 \mathrm{~cm})$ and dead yellowtail tetra Astyanax altiparanae as a baitfish. Those fish were transported to the Laboratory of Fish Biotechnology, ICMBio - CEPTA, anesthetized with clove oil solution $\left(0.1 \mathrm{~g} \mathrm{~L}^{-1}\right.$, Biodinâmica ${ }^{\circledR}$, Ibiporã-PR, Brazil) and the parameters of total length (TL), standard 
length (SL) and weight (W) were obtained. Each fish was tagged with a microtransponder, injected in the muscle at the base of the dorsal fin using a transponder injector. Seven extra fish specimens were euthanized using concentrated clove oil solution $\left(1 \mathrm{~g} \mathrm{~L}^{-1}\right)$ and necropsied in order to evaluate their stomach contents.

After this, the fish were divided into 3 groups of 10 individuals each, and each one was allocated in 3000-L fiberglass tanks with constant water flow. The tanks were covered with a 1-mm nylon mesh in order to reduce light incidence, and PVC tubes $(2.5 \times 0.30 \mathrm{~m})$ were provided for shelter.

As soon the fish were allocated at the tanks, gavaging (forced feeding) and a prophylactic procedure were provided during four months, in intervals of 10 days. For gavaging, a grounded commercial feeding (55\% of crude protein) was hydrated (3 $\mathrm{L}$ of water for $1 \mathrm{~kg}$ of ration) and injected directly into the stomach of fish using a 50 -mL syringe attached to a human probe (inner diameter: $6.4 \mathrm{~mm}$; outer diameter: $8.0 \mathrm{~mm}$ ). The feed was injected until the apparent filling of the stomach, determined by palpation. The prophylactic procedure consisted in the injection of enrofloxacin 5\% (10 mg kg-1 Vencofarma $^{\circledR}$, Londrina-PR, Brazil), levamisole 7.5\% (8 $\mathrm{mg} \mathrm{kg}^{-1}$, Ripercol ${ }^{\circledR}$, Campinas-SP, Brazil) and a vitamin complex $\left(0.1 \mathrm{~mL} \mathrm{~kg}^{-1}\right.$, Potenay $^{\circledR}$, Campinas-SP, Brazil).

For the feed training trial, three diets were tested: frozen specimens of Astyanax altiparanae (tetra); bovine heart (heart) and frozen sardine fillet (sardine). The feedings were given daily, at $5 \mathrm{pm}$, in portions of $25 \mathrm{~g}$ and no more than three pieces of each of the feed type (three A. altiparanae specimens, three pieces of bovine heart and three pieces of sardine fillet). All feed pieces were attached to the bottom of the tanks using a wire and the feed consumption and integrity of each piece of feed were checked twice. The trial was initiated after 30 days of forced feed and lasted for 60 days (experimental days 0 to 60). After this period, all fish was fed with $175 \mathrm{~g}$ of each feed until day 90. After 30, 60 and 90 days of the feed training trial, parameters of length and weight were measured.

\subsection{Experiment II: P. mangurus reproduction}

After the 1st experiment, the resultant 21 females were fed with 10 specimens of $A$. altiparanae daily during four months. After this period, the fish were collected, anesthetized and induced to spawn. Nineteen females were selected for spawning trials, based on external characteristics (ventral bulging and hyperemia in the urogenital region). Fish were induced to spawn using the protocol proposed by (Arashiro et al., 2018). Females were injected with $0.6 \mathrm{mg} \mathrm{kg}-1$ of carp pituitary extract (CPE) followed by a second dose of $6 \mathrm{mg} \mathrm{kg}-1$ of CPE 6 hours afterwards. As control group, 19 wild-caught females were collected and immediately induced to spawn using the same procedures. Males were induced by a single dose of $2 \mathrm{mg} \mathrm{kg}-1$ of CPE at the same time of the second dose of the females. For sperm collection, males were euthanized 5-h after injection with an overdose of clove oil (1 g L-1, Biodinâmica ${ }^{\circledR}$, Ibiporã-PR, Brazil), the testis were removed and minced in Eagle's MEM solution pH 7.8 (Sigma \# M0268, St. Louis, USA) and the debris were removed in order to keep only the cell suspension. Oocytes were obtained by extrusion of females after 156 degree-hours (app roximately $6 \mathrm{~h}$ after the second dose of CPE at $26^{\circ} \mathrm{C}$ ), and then fecundity was estimated. The oocytes were inseminated and the gametes were activated using the hatchery water. Incubation was achieved in 60 -L incubators. Five captive females and five others collected from the river had Fecundity Rate $(\mathrm{FR}=\mathrm{n} \#$ of viable oocytes $\mathrm{x}$ 100/total $\mathrm{n} \#$ of oocytes) and Initial Fertility Rate $($ IFR $=\mathrm{n} \#$ of oocytes per gram $)$ evaluated

\subsection{Experiment III: P. mangurus juvenile feed training}

The embryos resultant from the $2^{\text {nd }}$ experiment were used for the $3^{\text {rd }}$ experiment. After the hatching, the larvae were reared $300 \mathrm{~L}$ incubators, with constant aeration and water flow, and were fed 4 to 6 times a day with Artemia nauplii and Prochilodus lineatus larvae until 30-days-age.

After this period, 63 juveniles were randomly separated and divided into 9 fiberglass tanks $(10 \mathrm{~L}$ each) at a density of 7 fish per tank, with constant water flow and aeration. The tanks were covered by a 1-mm nylon mesh in order to reduce light incidence as recommended in literature (Appelbaum and Mcgeer, 1998; Cestarolli, 2005; Feiden et al., 2008; Pereira et al., 2019)

After one week of acclimation, the experiment evaluating three different methods for feeding training was started. For this, were used three treatments: grounded bovine heart as control; grounded bovine heart with gradual ration increments until reaching $50 \%$ bovine heart and $50 \%$ commercial feeding; and grounded bovine heart with gradual increments until reaching $0 \%$ bovine heart and $100 \%$ commercial feeding. The gradual increase of the feed in treatments 2 and 3 was equivalent to 5 and $10 \%$ every week, respectively.

At the beginning of the experiment and each 7 days, weight and length were measured until the period of 10 weeks. The animals were observed 3 times a day for counting and removal of the dead fish.

Parameters of weight gain $(\mathrm{WG}=$ Final Weight Initial Weight), Growth (Final Length - Initial Length), Specific Growth Rate (SGR: [ln (Final Weight) $\ln$ (Initial Weight) $] / \mathrm{n}^{\circ}$ of days $\left.* 100\right)$ were calculated from each treatment.

\subsection{Statistics}

The data are expresses as mean \pm standard error of mean (SEM). All data were evaluated for normality and homoscedasticity using the Cramer-Von Mises' and Levene's tests, respectively. For FR and IFR, a t-test was used. For the other parameters, a two-way ANOVA was performed and the means were compared with Tukey's multiple range test $(\alpha=5 \%)$. The feed consumption data were treated qualitatively. 


\section{Results}

\subsection{Experiment I: domestication of wild-caught P. mangurus}

The food consumption of wild-caught $P$. mangurus, expressed qualitatively in Figure 1A, showed that the tetra feeding was more rapidly accepted than heart and sardine in the first month of trial. After day 60 of trial, the fish accepted all the food offered. No significant differences were observed in the total weight (Figure 1B and 1D) or standard length (Figure 1C and 1E) for males or females during all the experimental period. No deaths were observed until the end of the experiment period.

Based on the results above, in which the natural food item yellowtail tetra as food source gave rise to good results, this was the treatment chosen to feed the animals until the spawning period and for experiment II.

\subsection{Experiment II: P. mangurus reproduction}

Among the domesticated P. mangurus females, kept in tanks for seven months and fed ad libitum with yellow tail tetra diet, 19 of 21 captive females have a positive response to hypophysation method. No differences were observed in the RIF $(P$-value $=0.2660)$ between wild and domesticated fish (Figure 2B) and, although significant lower, the difference of FR of fish reared in captivity in comparison with wild fish was $(P$-value $=0.0415)$ lesser than $10 \%$ (Figure 2A).

\subsection{Experiment III: juvenile feed training}

The zootechnical parameters of the P. mangurus juveniles submitted to three different diets for 10 weeks is shown on Figures 3, 4 and 5. The increase observed in standard length (Figure 3A) and live weight (Figure 4A) was due the natural
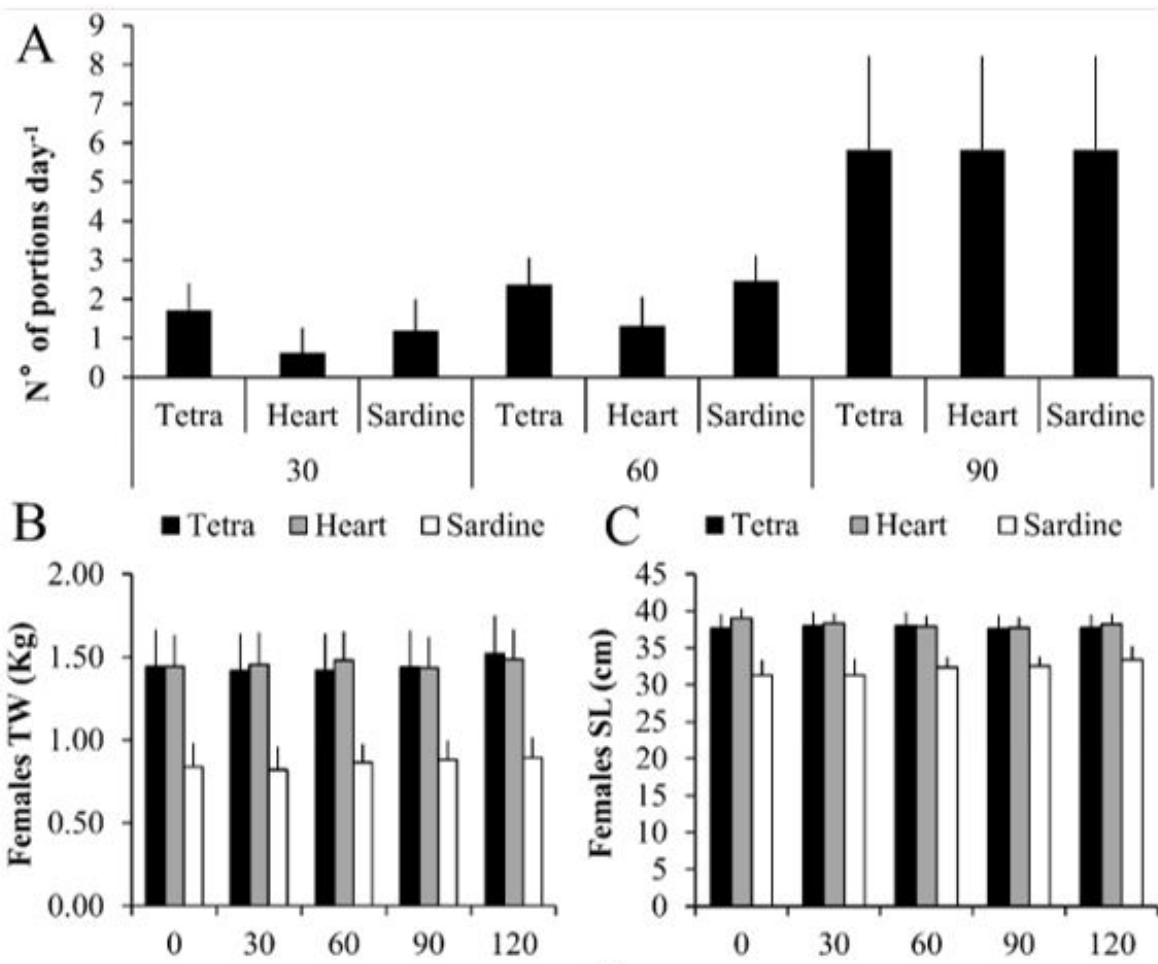

C $₫$ Tetra $\square$ Heart $\square$ Sardine
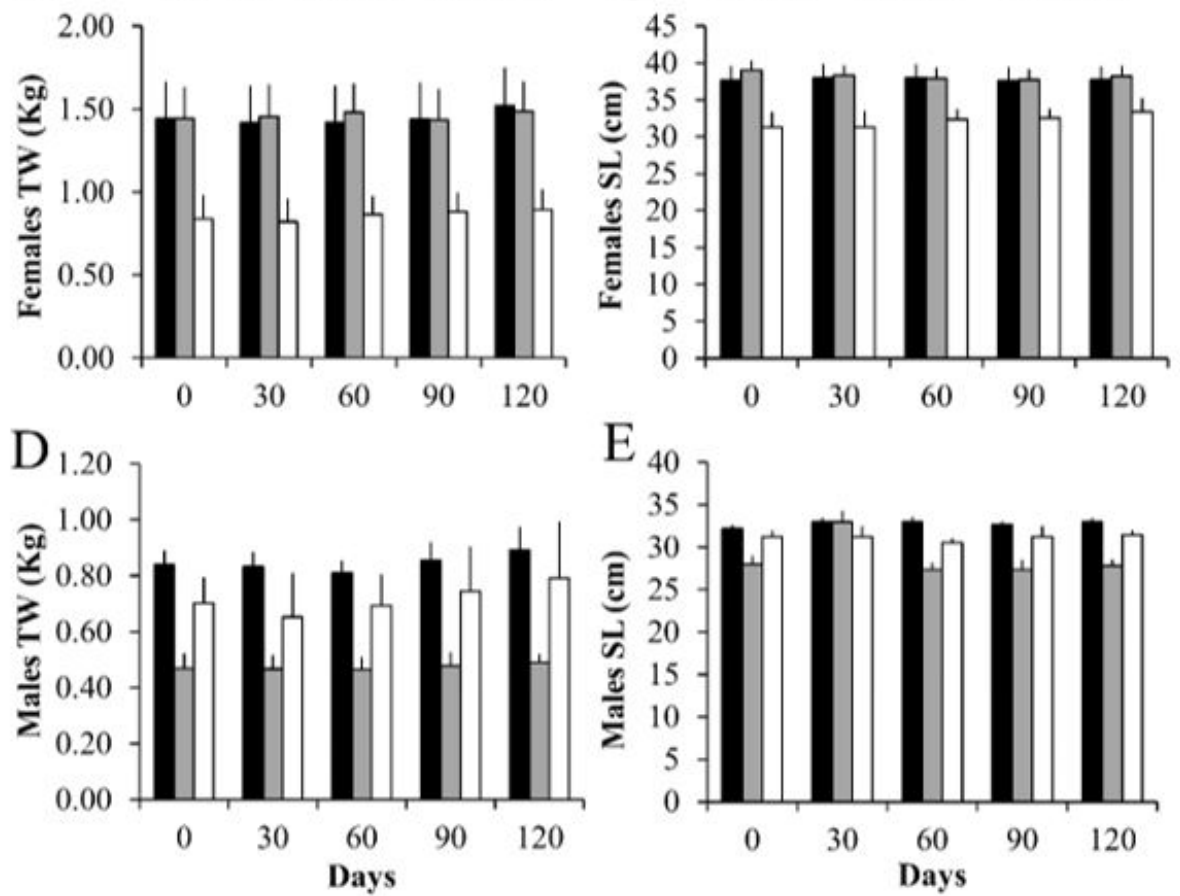

Figure 1. Zootechnical parameters of $P$. mangurus fed with tetra fish, bovine heart and sardine. (A) Feed consumption $(n=30)$; Total weight (B) and standard length $(C)$ of females $(n=21)$; Total weight (D) and standard length (E) of males $(n=9)$. 

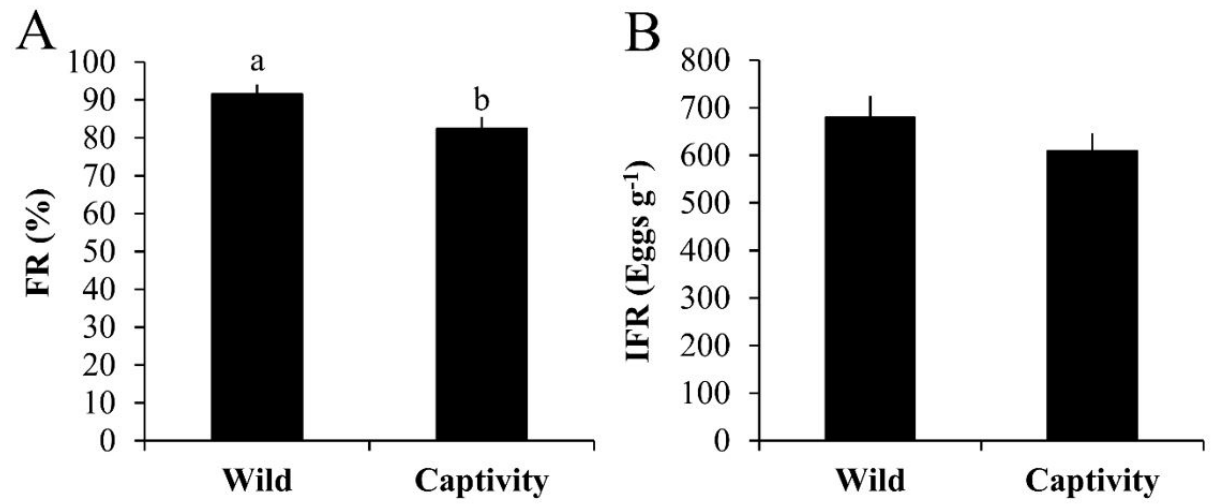

Figure 2. Fertilization rate (A) and relative initial fertility (B) of domesticated and wild P. mangurus.

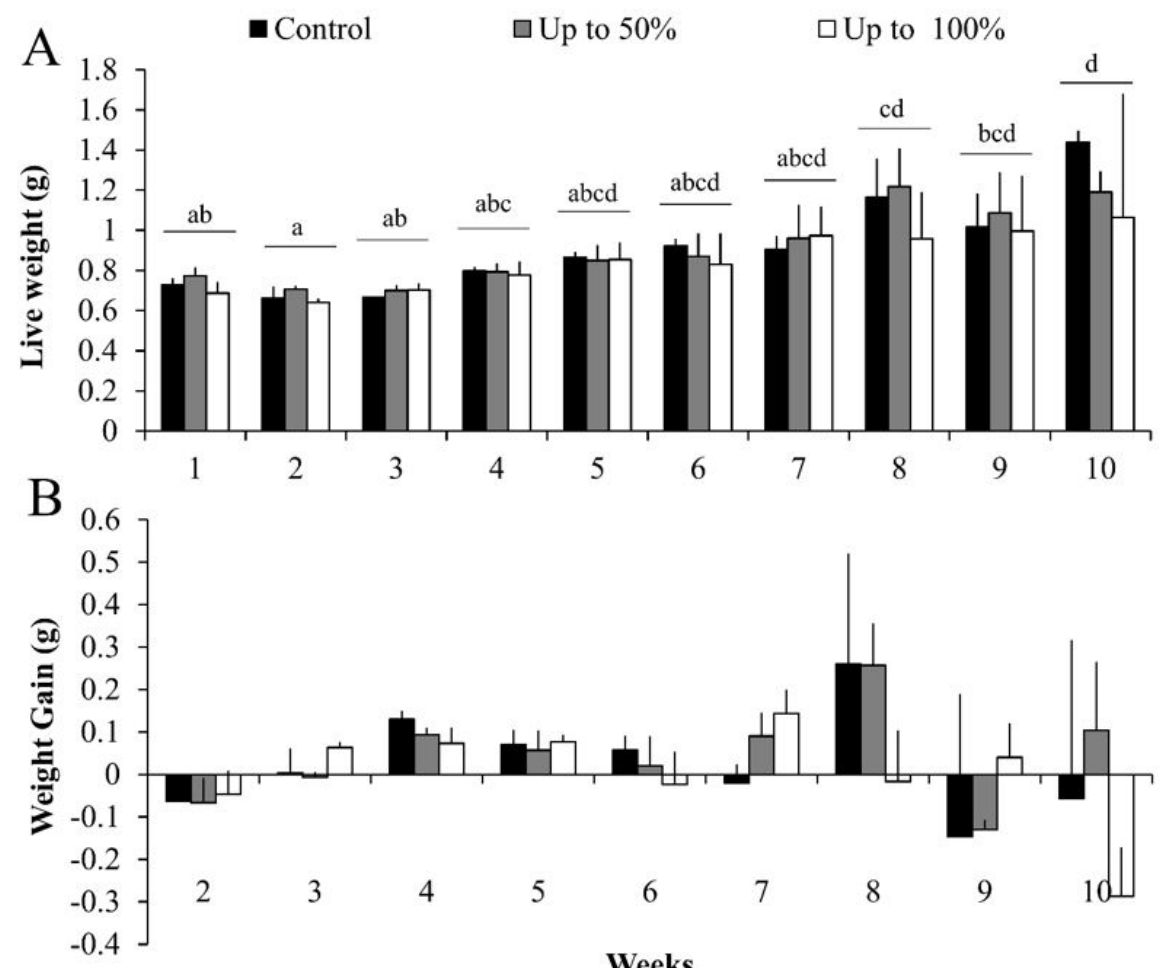

Figure 3. Live weight (A) and weight gain (B) of P. mangurus juveniles fed with three experimental diets (bovine heart; bovine heart gradually substituted with up to $50 \%$ of commercial feed; and bovine heart substituted with up to $100 \%$ of commercial feed, $n=63)$. Different letters mean significant differences according to Tukey`s test $(\alpha=5 \%)$.

growth of fish and did not differ among the experimental diets. Hence, no significative differences were observed in weight gain (Figure 3B) and growth (Figure 4B).

The total weight gain was $0.50 \pm 0.20 \mathrm{~g}$ and the average weight gain was $0.02 \pm 0.09 \mathrm{~g} \mathrm{week}^{-1}$ (minimum -0.08 at the 8 th week and a maximum of $0.17 \mathrm{~g}$ week- 1 at the 9 th and 10th weeks). The standard length, which was $37.14 \pm 0.68 \mathrm{~mm}$ in the $1^{\text {st }}$ week, was $46.30 \pm 1.87 \mathrm{~mm}$ in the $10^{\text {th }}$ week. Total growth was $9.16 \pm 1.19 \mathrm{~mm}$ and the average growth was $0.93 \pm 0.61 \mathrm{~mm}^{-1}$ week $^{-1}$ (minimum of 0.21 in the 7 th week and maximum of 1.31 in the 5 th week).
Although no significant differences were found between the experimental treatments, the feed with half bovine heart and half commercial feed showed the higher values of weight gain $(0.10 \pm 0.16 \mathrm{~g})$, specific growth rate $(0.37 \pm 0.11 \mathrm{~mm})$, highest length $(47.78 \pm 2.35 \mathrm{~mm})$ and growth $(2.15 \pm 2.27 \mathrm{~mm})$ values observed in the $10^{\text {th }}$ week (Figure 5A). The survival of juveniles of P. mangurus also showed no significant differences within treatments, however, fish fed with the treatment with $100 \%$ of bovine heart substitution with commercial feed presented the higher survival of juveniles in the long term. Survival decreased 


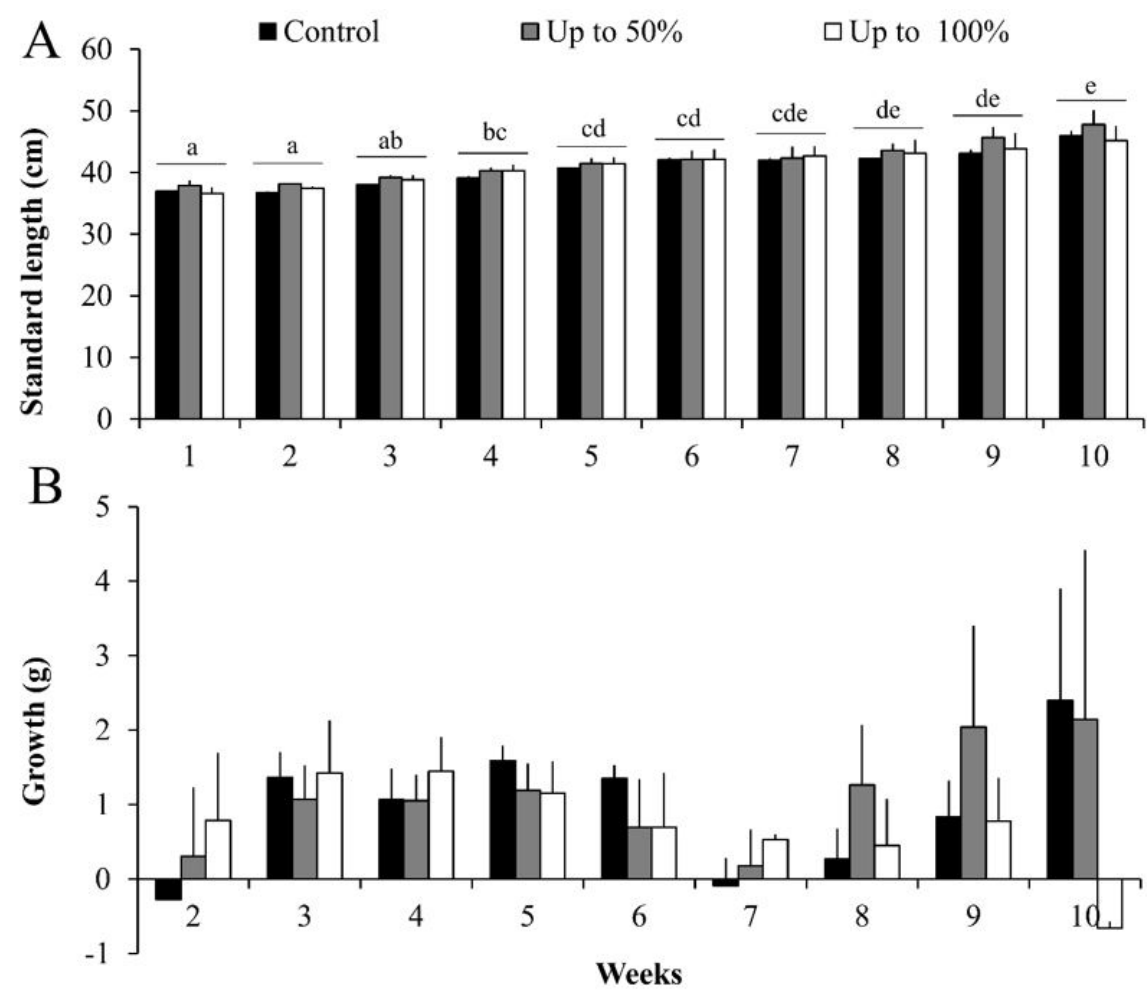

Figure 4. Standard length (A) and Growth (B) of P. mangurus juveniles fed with three experimental diets (bovine heart; bovine heart gradually substituted with up to $50 \%$ of commercial feed; and bovine heart substituted with up to $100 \%$ of commercial feed, $n=63)$. Different letters mean significant differences according to Tukey`s test $(\alpha=5 \%)$.
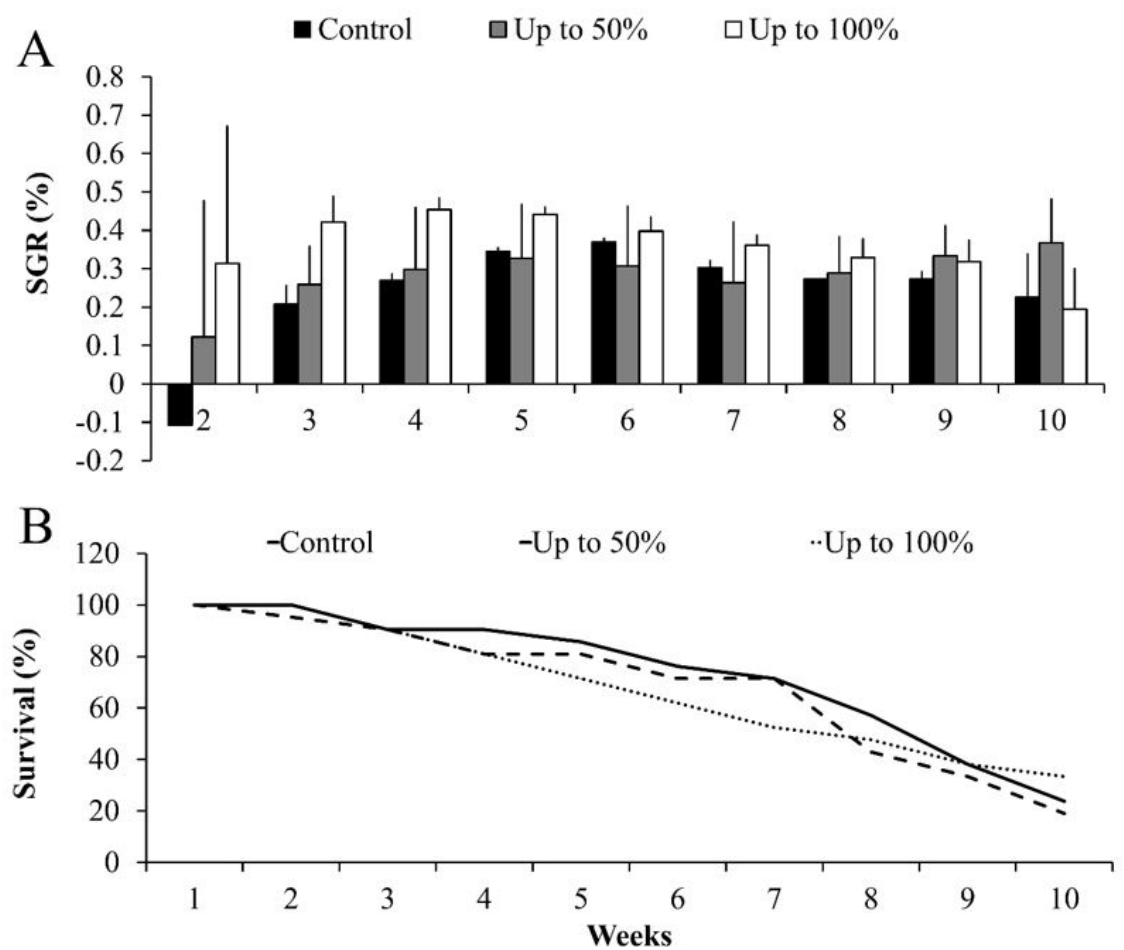

Figure 5. Specific growth rate $(A)$ and survival (B) of $P$. mangurus juveniles fed with three experimental diets (bovine heart; bovine heart gradually substituted with up to $50 \%$ of commercial feed; and bovine heart substituted with up to $100 \%$ of commercial feed, $\mathrm{n}=63$ ). 
approximately $5 \%$ per week until the 7 th week. After the 8 th week the survival reached $50 \% \pm 7 \%$ ), and decreased more than $8 \%$ per week until reaching a mean of $24 \pm 7 \%$ at the end of the experiment (Figure 5B).

\section{Discussion}

Feeding management in Siluriformes is still challenging for many species as in the case of P. mangurus, and this study is the first report for the species. The forced feeding procedure proposed here can be considered only in extreme starvation situations, in the absence of alternatives for the maintenance of captive specimens, and its long-term use is impracticable. The analysis performed in the experiment showed no preference among the provided feeds, however, the tetra diet presented a faster acceptance than the other 2 treatments (sardine and bovine heart) and it is the diet that comes closest to $P$. mangurus natural diet, being $A$. altiparanae used as bait and observed in the stomach content of $P$. mangurus that died during collection and were necropsied. For this reason, the $A$. altiparanae diet is used from the end of experiment I and throughout experiment II for all animals.

After the acceptance of artificial feeding, most of the female fish were able to spawn and presented similar reproductive performance with wild specimens collected during the spawning season which were then presumably in good conditions. Moreover, the fertilization rates observed here $(82 \%)$ was considerably higher than the presented for other neotropical Siluriformes species: 59\% for Lophosilurus alexandri (Santos et al., 2013a), 60\% for Trachelyopterus galeatus (Santos et al., 2013b), 69.5\% for Steindachneridion parahybae (Honji et al., 2012) and $72.4 \%$ for Rhinelepis aspera (Perini et al., 2010), indicating that that our management provided gonadal maturation, with a similar egg weight and size and a complete oocyte vitellogenesis, which are important for reproductive success (Wallace \& Selman, 1981).

The reproduction per se is not the final step for species maintenance. The survival of juveniles is also a critical stage which will provide the juveniles for restocking programs or fish farming intent. In this study, we evaluate the performance in response to two different levels of bovine heart substitution to establish a procedure of feeding management to the P. mangurus juveniles. Although no significant difference observed due to the different diets, the diet with the final concentration of $100 \%$ of commercial diet resulted in the higher survival rate of the juveniles. Our findings contrast with the presented by (Diemer et al., 2001), working with Pimelodus britskii and feeding them with artemia nauplii plus feed, observing a much higher weight and length gains and a survival of $94 \%$. However, factors such as predatory and competitive behavior result in high cannibalism and represent a major obstacle to juvenile survival rates in the cultivation of carnivorous Siluriform species. (Luz et al., 2011) carried out black bass (Micropterus salmoides) feeding training using formulated diet mixture, achieving better results when compared to formulated diet mixture and bovine heart. (Salaro et al., 2012) observed interesting results using gelatin as a moist ingredient in the feed training of giant trahira Hoplias $c f$. lacerdae, which may be an alternative to the training of $P$. mangurus juveniles.

In conclusion, the present study was successful in the domestication of wild-caught $P$. mangurus until the stage of reproduction, demonstrating that the reproductive performance in captivity can be similar with wild-caught species during the spawning season. Our findings serve as starting point for future studies that may contribute for the exploration and conservation of this and others threatened native species. Finally, more studies have to be done to improve the zootechnical gains and survival of the juveniles, making the P. mangurus production completely independent from the natural environment.

\section{Acknowledgements}

The authors are grateful to ICMBio/CEPTA for the for gently provide the facilities and experimental fish, and AES Tietê (Research \& Development Project \#0064-1052/2014) for financial support.

\section{References}

APPELBAUM, S. and MCGEER, J.C., 1998. Effect of diet and light regime on growth and survival of African catfish (Clarias gariepinus) larvae and early juveniles. Aquaculture Nutrition, vol. 4, no. 3, pp. 157-164. http://dx.doi.org/10.1046/j.13652095.1998.00064.x.

ARASHIRO, D.R., YASUI, G.S., CALADO, L.L., NASCIMENTO, N.F., SANTOS, M.P., SANTOS, S.C.A., LEVY-PEREIRA, N., MONZANI, P.S., SIQUEIRA-SILVA, D.H. and SENHORINI, J.A., 2018. Synchronizing developmental stages in Neotropical catfishes for application in germ cell transplantation. Zygote (Cambridge, England), vol. 26, no. 2, pp. 135-148.

CARVALHO, M.S., RIBEIRO, K.D., MOREIRA, R.M. and ALMEIDA, A.M., 2017. Concentração de metais no rio Doce em Mariana, Minas Gerais, Brasil. Acta Brasiliensis, vol. 1, no. 3, pp. 37. http://dx.doi.org/10.22571/Actabra13201758.

CESTAROLLI, M. A., 2005. Larvicultura do pintado Pseudoplatystoma coruscans (Agassiz, 1829): aspectos da alimentação inicial e do desenvolvimento de estruturas sensoriais. Jaboticabal: Universidade Estadual Paulista, 110 p. Tese de doutorado em Aquicultura.

COMIZZOLI, P. and HOLT, W.V., 2014. Recent advances and prospects in germplasm preservation of rare and endangered species. New York: Springer, pp. 331-356. http://dx.doi. org/10.1007/978-1-4939-0820-2_14.

DIEMER, O., NEU, D.H., SARY, C., FEIDEN, A., BOSCOLO, W.R. and SIGNOR, A.A., 2001. Manejo alimentar na larvicultura do mandi-pintado ("Pimelodus britskii"). Revista Brasileira de Saúde e Produção Animal, vol. 11, no. 3, pp. 903-908.

FEIDEN, A., FERRARI, E., BOSCOLO, W.R., FREITAG, M., COLDEBELlA, A., HINNAH, L. and SIGNOR, A.A., 2008. Desempenho e sobrevivência de alevinos de black bass (Micropterus salmoides, Lacepède 1802), submetidos ao condicionamento alimentar, utilizando diferentes patês protéicos. Semina: Ciências 
Agrárias, vol. 29, no. 2, pp. 449. http://dx.doi.org/10.5433/16790359.2008v29n2p449.

GORDA, S., BAKOS, J., LISKA, J. and KAKUK, C., 1995. Live gene bank of common carp strains at the Fish Culture Research Institute, Szarvas. Aquaculture (Amsterdam, Netherlands), vol. 129 , no. 1-4, pp. 199-202. http://dx.doi.org/10.1016/00448486(94)00248-M.

HONJI, R.M., TOLUSSI, C.E., MELLO, P.H., CANEPPELE, D. and MOREIRA, R.G., 2012. Embryonic development and larval stages of Steindachneridion parahybae (Siluriformes: Pimelodidae): implications for the conservation and rearing of this endangered Neotropical species. Neotropical Ichthyology, vol. 10, no. 2, pp. 313-327. http://dx.doi.org/10.1590/S1679-62252012005000009.

INSTITUTO CHICO MENDES DE CONSERVAÇÃO DA BIODIVERSIDADE - ICMBIO, 2018. Livro vermelho da fauna brasileira ameaçada de extinção. Brasília: ICMBio.

LOPES, N., DE FREITAS, R. and ROCHA FILHO, R., 2019. How many more Brumadinhos and Marianas Will We be faced with yet? Journal of the Brazilian Chemical Society, vol. 30, no. 4, pp. 681-682. http://dx.doi.org/10.21577/0103-5053.20190034.

LUZ, R.K., SANTOS, J.C.E., PEDREIRA, M.M. and TEIXEIRA, E.A., 2011. Effect of water flow rate and feed training on "pacamã" (Siluriforme: Pseudopimelodidae) juvenile production. Arquivo Brasileiro de Medicina Veterinária e Zootecnia, vol. 63, no. 4, pp. 973-979. http://dx.doi.org/10.1590/S0102-09352011000400024.

PEREIRA, L.F., CRUZ, G.D.B. and GUIMARÃES, R.M.F., 2019. Impactos do rompimento da barragem de rejeitos de Brumadinho, Brasil: uma análise baseada nas mudanças de cobertura da terra. Journal of Environmental Analysis and Progress, vol. 4, no. 2, pp. 122. http://dx.doi.org/10.24221/jeap.4.2.2019.2373.122-129.

PERINI, V. R., SATO, Y., RIZZO, E. and BAZZOLI, N., 2010. Biology of eggs, embryos and larvae of Rhinelepis aspera (Spix \&amp; Agassiz, 1829) (Pisces: siluriformes). Zygote (Cambridge, England), vol. 18, no. 2, pp. 159-171. http://dx.doi.org/10.1017/ S0967199409990165. PMid:19860989.

RUDORFF, N., RUDORFF, C.M., KAMPEL, M. and ORTIZ, G., 2018. Remote sensing monitoring of the impact of a major mining wastewater disaster on the turbidity of the Doce River plume off the eastern Brazilian coast. ISPRS Journal of Photogrammetry and Remote Sensing, vol. 145, pp. 349-361. http://dx.doi.org/10.1016/j. isprsjprs.2018.02.013.

SALARO, A.L., OLIVEIRA JUNIOR, J.C., PONTES, M.D., OLIVEIRA, K.R.B., NEVES, I.G.A.A., FERRAZ, R.B., HISANO, H. and ZUANON, J.A.S., 2012. Replacement of moist ingredients in the feed training of carnivorous fish. Revista Brasileira de Zootecnia, vol. 41, no. 10, pp. 2294-2298. http://dx.doi.org/10.1590/ S1516-35982012001000022.

SANTOS, H.B., ARANTES, F.P., SAMPAIO, E.V. and SATO, Y., 2013b. Artificial reproduction and reproductive parameters of the internally inseminated driftwood catfish Trachelyopterus galeatus (Siluriformes: auchenipteridae). Ichthyological Research, vol. 60, no. 2, pp. 142-148. http://dx.doi.org/10.1007/s10228-012-0324-9.

SANTOS, H.B., SAMPAIO, E.V., ARANTES, F.P. and SATO, Y., 2013a. Induced spawning and reproductive variables of the catfish Lophiosilurus alexandri Steindachner, 1876 (Siluriformes: pseudopimelodidae). Neotropical Ichthyology, vol. 11, no. 3, pp. 607-614. http://dx.doi.org/10.1590/S1679-62252013000300014.

SANTOS, M.P., NASCIMENTO, N.F., YASUI, G.S., PEREIRA, N.L., FUJIMOTO, T., SENHORINI, J.A. and NAKAGHI, L.S.O., 2018. Short-term storage of the oocytes affects the ploidy status in the yellowtail tetra Astyanax altiparanae. Zygote (Cambridge, England), vol. 26, no. 1, pp. 89-98. http://dx.doi.org/10.1017/ S0967199417000739. PMid:29334036.

SCHUINGUES, C., LIMA, M.G., LIMA, A.R., MARTINS, D.S. and COSTA, G.M., 2013. Anatomia da cavidade bucofaringeana de Sorubim trigonocephalus (Siluriformes, Osteichthyes). Pesquisa Veterinária Brasileira, vol. 33, no. 10, pp. 1256-1262. http:// dx.doi.org/10.1590/S0100-736X2013001000011.

SOBJAK, T.M., ROMÃO, S., NASCIMENTO, C.Z., SANTOS, A.F.P., VOGEL, L. and GUIMARÃES, A.T.B., 2017. Assessment of the oxidative and neurotoxic effects of glyphosate pesticide on the larvae of Rhamdia quelen fish. Chemosphere, vol. 182, pp. 267-275. http://dx.doi.org/10.1016/j.chemosphere.2017.05.031. PMid:28500971

SUGIEDA, A.M., KIERULF, M.C.M. and BRESSAN, P.M. Fauna ameaçada de extinção no estado de São Paulo - Vertebrados. São Paulo: SMA/SP - Secretaria de Meio Ambiente do Estado de São Paulo, 2010.

WAGNER, S., CASTRO, D., TOLEDO, J. J., ROSA, C. A. S., GODOI, D. S. (2002). [viewed 16 December 2019]. Larvicultura de Pintado (Pseudoplatystoma sp) em Alta Floresta - Mato Grosso [online]. Campina Grande: Universidade Estadual da Paraíba. Available from: http://agris.fao.org/agris-search/search. do?recordID=AV20120161899

WALLACE, R.A. and SELMAN, K., 1981. The reproductive activity of Fundulus heteroclitus females from woods hole, Massachusetts, as compared with more southern locations. Copeia, vol. 1981, no. 1, pp. 212. http://dx.doi.org/10.2307/1444058. 